WHO PAYS FOR PROTECTION IN AUSTRALIA?

Kwang-Ho Choi

The University of Western Australia

Discusion Paper 85.09

Augu st 1985

ISSN $0811-6067$

ISBN 0864227299 
August 1985

WHO PAYS FOR PROTECTION IN AU STRALIA?

$$
\text { by }
$$

Kwang-Ho Choi *

Department of Economics

The University of Western Australia

This paper is a chapter of my M.Ec. thesis entitled Economic Aspects of Protection. I am grateful to Professor Kenneth w. Clements for his constructive comments and guidance; and to $\mathrm{Kal}$ stening for her invaluable help. 
1.

2.

True Tariffs and Subsidies

The Transfers Amongst Economic Agents

The Real Income of Consumers

The Real Income of Consumers and

the Government

Are Conditions (5) and (6) Likely

to be Satisfied?

The Structure of the Australian Economy

Nominal Protection

The True Tariff and The True Export Tax

Do Australian Consumers Gain from Protection?

The Position of Consumers and the Government in Australia

The Transfer Matrix

Nomina1 Protection with Wages

Increasing has the Same Effects as

True Protection with Wages Constant 
INTER-SECTORAL TRANSFERS ARISING FROM PROTECTION (As a fraction of G.D.P.)

WEIGHTED AVERAGE NOMTNAL RATES OF ASSISTANCE FOR EXPORTS: AU STRALIA, 1979-80

INTER-SECTORAL TRANSFERS ARISING FROM PROTECTION: AU STRALIA, 1979-80

(As a Percentage of G.D.P.)

CLASSIFICATION OF MANUFACTURING INDUSTRIES: AUSTRALIA, 1979-80 


\section{INTRODU CTION}

Who pays for protection? The intelligent layperson might wel1 argue that the answer is very straightforward: It is the importer who pays for import tariffs and the like as it is he who writes the cheque payable to the collector of Customs. As is well known in èconomics, however, that is only part of a long story. It is likely that the importer will be able to pass on most, if not all, of the import duties to his customers in the form of higher prices. Thus, the consumers of imports pay for protection in the form of higher prices. But this is still only an intermediate step in a long process as many consumers are also wage earners. Wage earners will push for higher wages (and other forms of compensation) to counter the higher cost of living. In addition, many other types of costs and charges are tied to the cost of living index, so that these other costs will also be inflated as a result of protection. Other consumers who may be pensioners would be likely to lobby the government for increases in their pensions to maintain the real value of what they see as they justifiably-deserved welfare payments. Consequently, protection will have the effects of increasing wages and other costs and charges, as well as the country's welfare bill, which means higher taxation.

How do these effects impinge on industry at home? The firms in the import-competing sector clearly gain from import protection as it has the effect of raising the internal prices of the competing imports. However, there is an offset to this beneficial effect on account of the fact that the costs of the import-competing firms will also rise. Costs increase because protection has the effect of increasing wages, other costs and taxation, as indicated above. The net position of the 
import-competing firms depends on the balance between their higher revenues and higher costs. As a result, the calculation of the net position requires further analysis.

However, the position is quite unambiguous for the country's exporters: They lose. The exporters are hit with the higher costs in exactly the same way as are the firms in the import-competing sector. However, there is no offsetting benefit for exporters. Most exporters sell in highly competitive world markets which are characterized by nearperfectly elastic demand schedules. Consequently, the prices received by exporters is entirely outside their control, implying that there is no scope for passing on cost increases in the form of higher prices. The exporters are squeezed by protection.

These ideas have been elaborated in a simple and concise manner in a recent book by clements and Sjaastad (1985). They develop a simple general equilibrium model which emphasises the shifting of the burden of protection from one sector to another. The model makes possible the measurement of the ultimate effects of protection in a straightforward manner. In this paper we apply this model to measure the ultimate effects of protection in Australia. This analysis enables us to measure the transfers of income from one sector to another resulting from protection.

The structure of the paper is as follows. Section 2 sets out the Clements-Sjaastad model. Section 3 contains the application to Australia. That includes a discussion of the structure of the Australian economy; the measurement of protection; and the measurement of the transfers implicit in Australian protection, in the form of a transfer matrix (giving the income transfers from sector $i$ to sector $j$, 
where $i, j=$ import-competing firms, exporters, consumers and taxpayers). The key finding of this section is that Australian exporters are subject to a tax by about 1.5 percent of G.D.P. as a result of protection. Concluding comments are given in Section 4.

2. THE MODEL

The model is from clements and Sjaastad (1985) and it is about the inter-sectoral transfers of: income arising from protection. It is only concerned with the transfers, ignoring any deadweight or welfare costs of protection.

True Tariffs and Subsidies

Protection policy can be described as protecting certain industries relative to others. The clements and Sjaastad model studies the change in the relative prices arising from protection. The analysis of the change in the relative prices gives rise to the concept of true protection to each economic agent, which leads to the transfers amongst economic agents.

It can be shown that (in the absence of complementarity) the price of home goods is related to commercial policy as follows:

$$
d=s+\omega(t-s) ;
$$

where

$d=$ proportional increase in the price of home goods; $s$ = weighted average subsidy equivalent of the export subsidies and other forms of assistance to exporters; 
$t=$ weighted average tariff equivalent of the actual ad-valorem tariffs and other forms of assistance to firms in the import-competing sector;

and $w$ is a coefficient lying between 0 and 1 .

From equation ( 1 ), if $t=s$, we have $t=s=d$ which is the same as a devaluation of $100 \times t$ percent when trade is balanced. In other words, if we try to protect all, we end up protecting no one as all relative prices are unaffected. As home goods are mainly services, which are labour intensive, we can interpret $d$ as approximately measuring the percentage increase in nominal wages.

Equation (1) can be rearranged as follows:

$$
d=\omega t+(1-\omega) s,
$$

This equation shows that the increase in the home goods price is a weightedaverage of the equivalent import duty and export subsidy. The coefficient of $t$ is known as "the shift coefficient". It indicates the degree of substitution possibilities amongst the three sectors; this ultimately determines the incidence of protection. For example, if $\omega$ is zero, we have $d=s$ which implies that home goods and exportables are. perfect substitutes. Here the incidence of protection is equally shared by producers of home goods and exportables. At the other extreme, if $\omega=1$, then ( ${ }^{\prime}$ ) gives $d=t$ which implies that home goods and importables are perfect substitues and the incidence of protection is entirely borne by exporters. 
Choosing units so that all prices under free trade are unity, we define the true tariff $t^{*}$ and the true subsidy $s^{*}$ as the change in the internal prices of importables $\left(P_{m}\right)$ and exportables $\left(P_{x}\right)$, respectively, relative to that of home goods $\left(P_{h}\right)$ :

$$
\begin{aligned}
& t^{*}=\Delta\left(\frac{P_{m}}{P_{h}}\right)=\frac{1+t}{1+d}-1=\frac{t-d}{1+d} \\
& s^{*}=\Delta\left(\begin{array}{l}
P_{x} \\
P_{h}
\end{array}\right)=\frac{1+s}{1+d}-1=\frac{s-d}{1+d} .
\end{aligned}
$$

These expressions for the true tariff and true subsidy give us a very important policy implication. From equation (1),

$$
\omega=\frac{d-s}{t-s} \text {. }
$$

Thus

$$
\begin{aligned}
& \omega t^{*}+(1-\omega) s^{*} \\
& =\left(\frac{d-s}{t-s}\right) \cdot\left(\frac{t-d}{1+d}\right)+\left(1-\frac{d-s}{t-s}\right)\left(\frac{s-d}{1+d}\right) \\
& =\left(\frac{d-s}{t-s}\right) \cdot\left(\frac{t-d}{1+d}\right)+\left(\frac{t-d}{t-s}\right) \cdot\left(\frac{s-d}{1+d}\right) \\
& =0,
\end{aligned}
$$

where the first step follows from (2) and (3). Thus, we have

$$
\omega t^{*}+(1-w) s^{*}=0
$$

In words, a weighted average of the true tariff and true subsidy is zero. Given that $\omega$ only depends upon substitution effects, $t^{*}$ and $s^{*}$ 
cannot be chosen independently. In other words, the policy maker can only choose the true tariff or the true subsidy, but not both because he does not controlw. To illustrate, if the policy maker wishes to deliver a certain amount of true protection to the import-competing industries of $t_{1}^{*}>0$, then this necessarily means that exporters will have to be taxed at the rate

$$
s_{1}^{*}=-\frac{\omega}{1-\omega} t_{i}^{*}<0
$$

The differences between true and nominal protection for the importcompeting sector is

$$
t^{*}-t=\frac{t-d}{1+d}-t=\frac{-(1+t) d}{1+d} .
$$

Similarly, the difference between the true and nominal export subsidy is

$$
s^{*}-s=\frac{s-d}{1+d}-s=\frac{-(1+s) d}{1+d} .
$$

If $t>0$ and $s>0$, then the two differences are both negative since d, the change of the price of home goods, is positive [see (1')]. Thus, true protection is less than the nominal protection. Only when $\mathrm{d}=0$ is true protection identical to nominal protection.

The Transfers Amongst Economic Agents

Nominal protection does not reveal the ultimate effects on the real incomes of the various economic agents. True protection is, however, we11-suited to measure these effects and in this sub-section we use true protection to form a transfer matrix which gives all the 
effects of protection in transferring income from sector $i$ to $j$ of the economy.

We define the production and consumption of importables and exportables and imports and exports in units of G.N.P. at world prices:

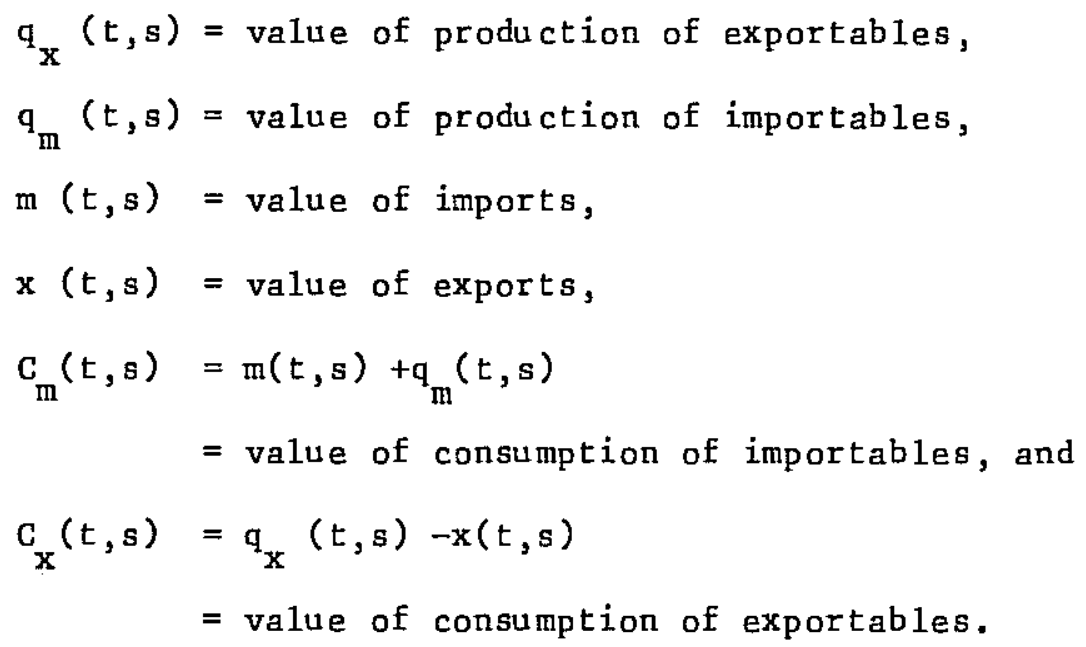

All of the above are functions of several variables, including domestic relative prices. For expositional simplicity, we have suppressed all such variables except $t$ and $s$, the uniform tariff and export subsidy equivalent of a11 forms of protection. For notational convenience, we shall now also suppress the variables $t$ and $s$ as arguments of $q_{x}, q_{m}, C_{x}, c_{m}$, $x$ and m. Economic agents are classified into the five overlapping groups, exporters, import-competing firms, consumers, taxpayers and the government. As the effects of nominal protection $t$ and $s$ can be exactly replicated by imposing $t^{*}$ and $s^{*}$ (with the price of home goods remaining constant), we shall analyze the implicit transfers in terms of $t^{*}$ and $s^{*}$.

From the relationship between the true tariff and the true subsidy given in equation (4), the true export subsidy $s^{*}$ or the true. tax $-s^{*}$ can be represented as:

$$
-s^{*}=\frac{\omega t^{*}}{1-\omega} .
$$


If we impose an export tax of $-s^{*}$ on the export sector, exporters lose income in proportion to the quantity that they produce. Hence, their total loss is:

$$
-s^{*} q_{x}=-s^{*}\left(C_{x}+x\right)=\frac{\omega t^{*} q_{x}}{1-\omega} .
$$

This exporter's loss is transferred to consumers in the form of paying less for exportables and to the government in the form of tax revenue. Consumers will get a net transfer from the exporters equal to

$$
-s^{*} C_{x}=\frac{w t^{*} C_{x}}{1-\omega}
$$

The government's revenue from the export tax is

$$
-\mathrm{xs}^{*}=\frac{\omega \mathrm{t}^{*} \mathrm{x}}{1-\omega} \text {. }
$$

If the import-competing sector receives true protection at the rate $t^{*}$, they will gain income in proportion to the value of production of importables,

$$
t^{*} q_{m}
$$

The gain of the import-competing sector comes entirely at the expense of consumers. It takes the form of consumers paying higher prices for importables. The government also gains from the tariff in the form of tariff revenue mt*. Hence, the consumer's total transfers to the import-competing sector and the government is:

$$
t^{*} q_{m}+t^{*} m=t^{*} c_{m}
$$


The government collects a total amount of $\omega^{*} x /(1-\omega)+t^{*}$ m from the protection policy, $\mathrm{mt}^{*}$ coming from consumers and $\omega t^{*} \mathrm{x} /(1-\omega)$ from exporters. However, assuming that this additional government revenue is used to reduce other forms of existing taxation, this will be transfered back to taxpayers so that they gain $t^{*}[m+\omega x /(1-\omega)]$. Therefore, the government will not have a net gain from protection.

The transfers between the economic agents are summarized in the form of a matrix in Table 1. The final column represents the total transfers from each sector and the final row shows that total transfers to each sector. The column for taxpayers serves to record the transfer from the government of the higher revenue from commercial policy back to taxpayers.

The Real Income of Consumers

We see from Table 1 that if $t^{*}>0$ exporters lose and that those in the import-competing sector gains as a result of protection. We shall now consider the effects of protection on the real income of consumers. There are two effects here which go in opposite directions. First, consumers gain from lower internal prices of exportables as a result of the export tax $-s^{*}$. Their gain is equal to

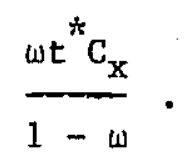

Second, they are taxed as a result of protection by having to pay higher prices for importables.- This tax is equal to

$$
\mathrm{t}^{*} \mathrm{c}_{\mathrm{m}}
$$


TABLE 1

INTER-SECTORAL TRANSFERS ARISING FROM PROTECTION

(As fractions of G.D.P.)

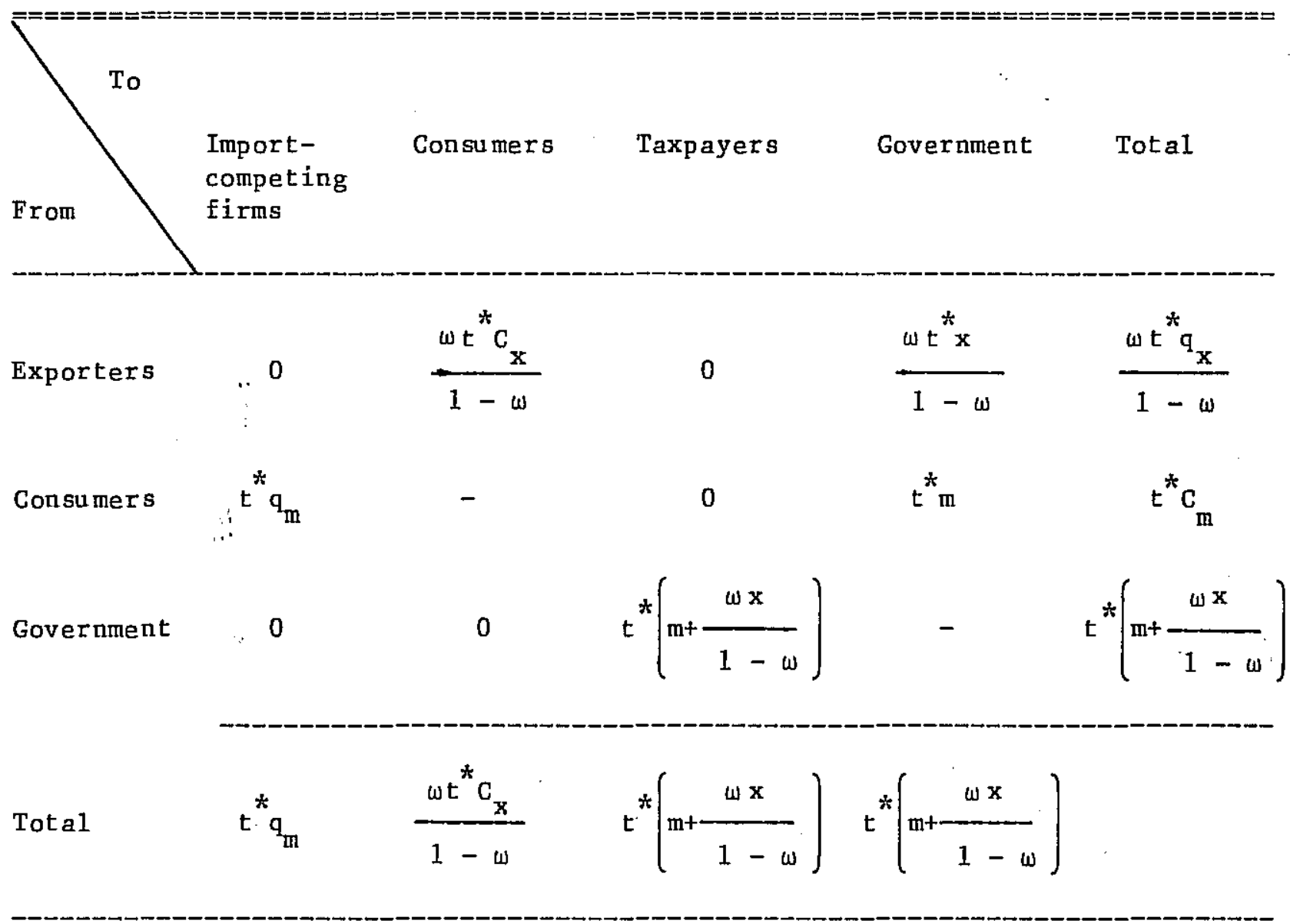


Combining the consumers' gain and loss of real income, their net position as a result of protection is

$$
T_{c}=\frac{\omega t^{*} C_{x}}{1-\omega}-t^{*} C_{m}=\frac{t^{*}\left[\omega C_{x}-(1-\omega) C_{m}\right]}{1-\omega} .
$$

If $T_{C}$ is positive, on balance consumers gain from protection. As $t^{*}$ and $(1-\omega)$ are both positive, $\mathrm{T}_{\mathrm{c}}>0$ when $\left[\omega \mathrm{C}_{\mathrm{x}}-(1-\omega) \mathrm{C}_{\mathrm{m}}\right]>0$. This condition may be expressed as

$$
\omega>\frac{\mathrm{C}_{\mathrm{m}}}{\mathrm{C}_{\mathrm{m}}+\mathrm{C}_{\mathrm{x}}} \text {. }
$$

In words, if the shift coefficient exceeds the share of importables in total consumption of tradeables, then consumers gain from protection.

The Rea1 Income of Consumers and the Government

Under the as sumption that the additional government revenue gets transferred back to consumers in the form of reductions in existing taxes (or that the government supplies useful services to consumers), we can consolidate these two sectors into the category consumers cum taxpayers.

The government revenue for protection is

$$
\mathrm{T}_{\mathrm{t}}=\mathrm{t}^{*}\left(\mathrm{~m}+\frac{\omega \mathrm{x}}{1-\omega}\right)=\frac{\mathrm{t}^{*}[\omega \mathrm{x}+(1-\omega) \mathrm{m}]}{1-\omega} .
$$

Hence, consumers cum taxpayers' total net gain is 


$$
\begin{aligned}
T_{t}+T_{c} & =\frac{t^{*}[\omega x+(1-\omega) m]}{1-\omega}+\frac{t^{*}\left[\omega C_{x}-(1-\omega) C_{m}\right]}{1-\omega} \\
& =\frac{t^{*}\left[\omega q_{x}-(1-\omega) q_{m}\right]}{1-\omega} .
\end{aligned}
$$

Consumers cum taxpayers experience a net gain if $T_{c}+T_{t}>0$. As $t$ * and $(1-\omega)$ are both positive, $T_{c}+T_{t}>0$ if $\left[\omega q_{x}-(1-\omega) q_{m}\right]>0$, i.e. if

$$
w>\frac{q_{m}}{q_{m}+q_{x}} \text {. }
$$

In words, if the shift coefficient exceeds the share of importables in the total production of tradeables, then consumers cum taxpayers are net gainers from protection.

Are Conditions (5) and (6) Likely to be Satisfied ?

For a given value of $\omega$, condition (5) is more likely to be satisfied when $\mathrm{C}_{\mathrm{m}} /\left(\mathrm{C}_{\mathrm{m}}+\mathrm{C}_{\mathrm{x}}\right)$ is low. That is, when the share of importables in the total consumption of tradeables is low; or, in other words, when the share of exportables is high. Consequently, condition (5) will be satisfied in countries where goods which are exported are also heavily consumed domestically. This is unlikely to be the case in countries like Chile and Australia where exports are dominated by primary products, the domestic demand for which is not significant. On the other hand, condition (5) is likely to be satisfied in a country like Argentina where there is substantial domestic consumption of beef, 
a major export.

Condition ( 6 ) is likely to be satisfied in most countries since w almost always exceeds .5 and domestic production of exportables is generally larger than the domestic production of importables. However, if import substitution is virtually complete and domestic production of exportables is very low, condition (6) can be reversed and consumers cum taxpayers would fail to gain from protection.

\section{APPLICATION TO AUSTRALIA}

This section has seven parts. First, the data for the construction of the Australia transfer matrix are presented. Second, we present the average nominal rates of assistance for imports and exports. Third, we compute the true tariff and true export tax for Australia. Fourth, we consider the question, do Australian consumers gain from protection? Fifth, we consider the position of consumers cum taxpayers. Sixth, we present the Australia transfer matrix. Finally, we show that nominal protection with wages increasing has exactly the same economic effects as does true protection with wages constant.

\section{The Structure of the Australian Econonmy}

To classify goods into exportables, importables and home goods, we use the information given in Australian National Accounts: Gross Product by Industry (ABS, 1982a) which disaggregates GDP into twelve industries:

(1) Agriculture, Forestry, Fishing and Hunting

(2) Mining 

(3) Manu facturing
(4) Electricity, Gas and Water
(5) Construction
(6) Wholesale and Retail Trade
(7) Transport, Storage and Communication
(8) Finance
(9) Public Administration and Defence
(10) Community Services
(11) Entertainment, etc \& Personal Services
(12) Ownership of Dwellings .

We classify as traded goods (1) Agriculture, Forestry, Fishing and Hunting, (2) Mining and (3) Manufacturing. The remaining industries $[(4)-(12)]$ can be regarded as home goods (non-traded).

Within the traded goods category, we classify (1) Agriculture, Forestry, Fishing and Hunting and (2) Mining as exportables. We divide up the manufacturing industry into exportables, importables and home goods; see Appendix for details. The resulting classfication of G.D.P. by indusry is shown in Table 2. Total home goods production in 1979-80 is $\$ 81,415$ million. The production of exportables and importables are $\$ 19,896$ and $\$ 14,395$ million, respectively. During the same year exports and imports are $\$ 18,579$ and $\$ 15,828$ million, respectively (see ABS, 1982b, p.38). We convert these values into fractions of G.D.P. by dividing them by $\$ 114,464$ million, G.D.P. In 1979-80. This yields :

Share of exportables production in G.D.P.

$$
q_{x}=\frac{19,896}{114,464}=.17 \text {. }
$$


TABLE 2

G.D.P. BY INW STRY : AU STRALIA, 1979-80

\begin{tabular}{|c|c|c|c|}
\hline Industry & $\begin{array}{l}\text { G.D.P. by } \\
\text { at Current } \\
\text { ( \$ mill }\end{array}$ & $\begin{array}{l}\text { Industry } \\
\text { Prices } \\
\text { ion ) }\end{array}$ & $\begin{array}{l}\text { Percentage of } \\
\text { Total G.D.P. }\end{array}$ \\
\hline
\end{tabular}

I. Exportables

Agriculture, Forestry, Fishing and Hunting

$$
\begin{aligned}
& 7,799 \\
& 7,468 \\
& 4,629
\end{aligned}
$$

Mining

Manu facturing

19.896

17

Tota1

II. Importables

Manufacturing

14,395

\begin{tabular}{|c|c|}
\hline Manufacturing & 4,570 \\
\hline Electricity, Gas and Water & 3,309 \\
\hline Construction & 7,315 \\
\hline Wholesale and Retail Trade & 15,995 \\
\hline $\begin{array}{l}\text { Transport Storage } \\
\text { and Communication }\end{array}$ & 7,947 \\
\hline Finance & 12,053 \\
\hline $\begin{array}{l}\text { Public Administration } \\
\text { and Defence }\end{array}$ & 4,634 \\
\hline Community Services & 11,971 \\
\hline $\begin{array}{c}\text { Entertainment, etc } \& \\
\text { Personal Services }\end{array}$ & 4,603 \\
\hline Ownership of Dwe1ling & 9,018 \\
\hline
\end{tabular}

III. Home Goods

Custom Duties

81,415

], 538

71

Less Imputed Bank Service Charge

2,780

$$
\text { G.D.P. }
$$

114,464

101

Source : ABS, (1982a, Table 3) and Appendix. 
Share of importables production in G.D.P.

$$
\mathrm{q}_{\mathrm{m}}=\frac{14,395}{114,464}=.13 .
$$

Share of home goods production in G.D.P.

$$
q_{h}=\frac{81,415}{114,464}=.71 \text {. }
$$

Share of exports in G.D.P.

$$
x=\frac{18,579}{114,464}=.16 \text {. }
$$

Share of imports in G.D.P.

$$
\mathrm{m}=\frac{15,828}{114,464}=.14 \text {. }
$$

We also have :

Share of exportables consumption in G.D.P.

$$
\mathrm{C}_{\mathrm{x}}=\mathrm{q}_{\mathrm{x}}-\mathrm{x}=.17-.16=.01
$$

Share of importables consumption in G.D.P.

$$
\mathrm{c}_{\mathrm{m}}=\mathrm{q}_{\mathrm{m}}+\mathrm{m}=.13+.14=.27 .
$$

The above information illustrates the structure of the Australian economy. As is usual in most cantries, production of home goods accounts for the largest fraction of G.D.P. What distinguishes the Australian economy is its emphasis on exports and also the negligible domestic consumption of exportables. This reflects, of course, the fact that Australia's main exportables are mineral and agricultural products. 


\section{Nominal Protection}

According to the Industries Assistance Commission Annual Report 1982-83 (IAC, 1983), the average nominal rate of assistance given to Australian manufacturing industries was 15 percent in 1979-80. This is the amount of assistance provided to the processes undertaken by an activity, industry etc. by measures such as tariffs, quotas, subsidies and other forms of protection, expressed as a percentage of the value of activity. We take 15 percent as the nominal ad valorem tariff equivalent of all forms of import protection. The precise average nominal rates of assistance for exports are not available. However, in 1975-76, the average nominal rate of assistance for exports of manufactured goods was .4 percent (IAC, 1978, Table 2.2.3). The agricultural sector, which we classify as exportables, received an average nominal assistance rate of 3 percent in 1979-80 (IAC, 1982, Table Al.3.2). Assuming that there is no assistance for the exports of mining products, we can approximate the average nominal rate of assistance for all exports as shown in Table 3. As can be seen, the weighted average rate is 1.3 percent. We shall thus use 1 percent as the approximate rate of nominal assistance given to Australian exporters. 
TABLE 3

WE IGHTED AVERAGE NOMINAL RATES OF ASSISTANCE FOR EXPORTS:

AU STRALIA, $1979-80$

\begin{tabular}{|c|c|c|c|c|}
\hline $\begin{array}{l}\text { Industry } \\
\text { (1) }\end{array}$ & $\begin{array}{l}\text { Value of } \\
\text { Production } \\
\text { (\$million) } \\
\text { (2) }\end{array}$ & $\begin{array}{l}\text { Share in total } \\
\text { exportables } \\
\text { (3) }\end{array}$ & $\begin{array}{l}\text { Nominal Rate of } \\
\text { Assistance } \\
\text { (Percent) } \\
\quad \text { (4) }\end{array}$ & $\begin{array}{l}\text { Weighted } \\
\text { Average } \\
(3) \times(4) \\
=(5)\end{array}$ \\
\hline Agricu 1ture & 7,799 & .39 & 3 & 1.17 \\
\hline Mining & 7,468 & .38 & 0 & 0 \\
\hline Manu facturing & 4,629 & .23 & .4 & .09 \\
\hline Total & 19,896 & 1.00 & & 1.26 \\
\hline
\end{tabular}

Source: As for Table 2, IAC (1978, Table 2.2.3) and IAC (1982, Table A1.3.2)

The True Tariff and The True Export Tax

Given $t=.15$ and $s=.01$, and using the Clements-Sjaastad (1985) w value for Australia of .7 , the effect of protection on the price of home goods (wages) is

$$
\begin{aligned}
d & =\omega t+(1-\omega) s \\
& =.7(.15)+(1-.7)(.01) \\
& =.105+.003 \\
& =.108 .
\end{aligned}
$$

Thus, nominal protection inflates nominal wages by almost 11 percent. The true tariff $t^{*}$ and the true export subsidy $s^{*}$ are : 
$\mathrm{t}^{*}=\frac{\mathrm{t}-\mathrm{d}}{1+\mathrm{d}}=\frac{.15-.008}{1+.108}=\frac{.042}{1.108}=.038$
$\mathrm{~s}^{*}=\frac{\mathrm{s}-\mathrm{d}}{1+\mathrm{d}}=\frac{.01-.108}{1+.108}=\frac{-.098}{1.108}=-.088$.

In words, the structure of protection in Australia implies a true tariff of 3.8 percent and a true export tax of 8.8 percent. As can be seen, true protection given to the import-competing sector is much less than nominal protection of 15 percent. The export tax of almost 9 percent is substantial and represents fairly harsh and discriminatory treatment of a highly-efficient sector of the Australian economy.

\section{Do Australian Consumers Gain from Protection?}

We use the above data to check whether or not the condition (5) holds. If it does, then Australian consumers gain from protection. The share of imports in total consumption is

$$
\frac{\mathrm{C}}{\mathrm{C}_{\mathrm{m}}+\mathrm{C}_{\mathrm{x}}}=\frac{.27}{.27+.01}=.96 .
$$

As this is greater than $\omega=.7$, we conclude that condition (5) is not satisfied, so that consumers do not gain from protection. Australian consumers do not gain simply because they are heavy consumers of importables and light consumers of exportables. Consequently, for consumers the tax base is high, while the base for the subsidy is low. 
The Position of Consumers and the Government in Australia

Next, we use (6) to test whether consumers cum taxpayers gain from import protection. The share of importables in total production of tradeables is

$$
\frac{q_{m}}{q_{m}+q_{x}}=\frac{.13}{.13+.17}=.43
$$

Thus, as $w=.7>.43$, condition (6) is satisfied. In other words, consumers cum taxpayers experience a net gain from protection. To put it yet another way, exporters lose more than import-competing firms gain. Given an $\omega$ value of: .7 , greater production of exportables $\left(q_{x}\right.$ $=.17)$ than importables $\left(q_{\mathrm{m}}=.13\right)$ implies that consumers cum taxpayers experience a net gain from import protection.

\section{The Transfer Matrix}

Given the previous information, we now construct the transfer matrix for Australia using the expressions given in Table 1.

The net loss of income for exporters ( as a fraction of G.D.P.) is

$$
\frac{\omega t^{*} q_{x}}{1-\omega}=\frac{.7 \times .038 \times .17}{1-.7}=\frac{.0045}{.3}=.0151 \text {. }
$$

Consumers get a transfer from exporters of

$$
-s^{*} C_{x}=\frac{\omega t^{*} C_{x}}{1-\omega}=\frac{.7 \times .038 \times .01}{1-.7}=\frac{.00027}{.3}=.00089 .
$$

The government revenue from the export tax is

$$
\frac{\omega t^{*} x}{11-\omega}=\frac{.7 \times .038 \times .16}{1-.7}=\frac{.00426}{.3}=.01419 .
$$


The total gain of the import-competing sector comes at the expense of consumers who pay higher prices for importables. This gain is

$$
\mathrm{t}^{*} \mathrm{q}_{\mathrm{m}}=.038 \times .13=.0049 .
$$

The tariff revenue collected by the government is

$$
\mathrm{mt}^{*}=.14 \times .038=.00532
$$

Therefore, the total transfer from consumers to others is

$$
\mathrm{t}^{*} \mathrm{C}_{\mathrm{m}}=\mathrm{t}^{*} \mathrm{q}_{\mathrm{m}}+\mathrm{t}^{*} \mathrm{~m}=.0049+.00532=.01022
$$

The government's total gain from protection is

$$
\mathrm{t}^{*}\left(\mathrm{~m}+\frac{\omega \mathrm{x}}{1-\omega}\right)=.038\left(.14+\frac{.7 \times .16}{1-.7}\right)=.01951 .
$$

However, as we as sume that this additional government revenue is used to reduce other forms of taxes, this becomes a gain to taxpayers. All these results are sumarized in Table 4. As can be seen, the gross gain to consumers cum taxpayers is $.09+1.95=2.04$ percent of G.D.P. in 1979-80. Due to the higher internal prices of importables, consumers in addition lose 1.02 percent, causing the net gain to consumers cum taxpayers to be $2.04-1.02=1.02$ percent of G.D.P.

Nominal Protection with Wages Increasing has the Same Effects as True Protection with Wages Constant

We have presented the transfers resulting from protection in terms of the true tariff $t^{*}$ and the true export subsidy $s^{*}$. As true protection embodies the change in wages resulting from nominal protection, it is unnecessary to explicitly consider the effects of the 
TABLE 4
INTER-SECTORAL TRANSFERS ARISING FROM PROTECTION : AU STRALIA, 1979-80
(As percentages of G.D.P.)

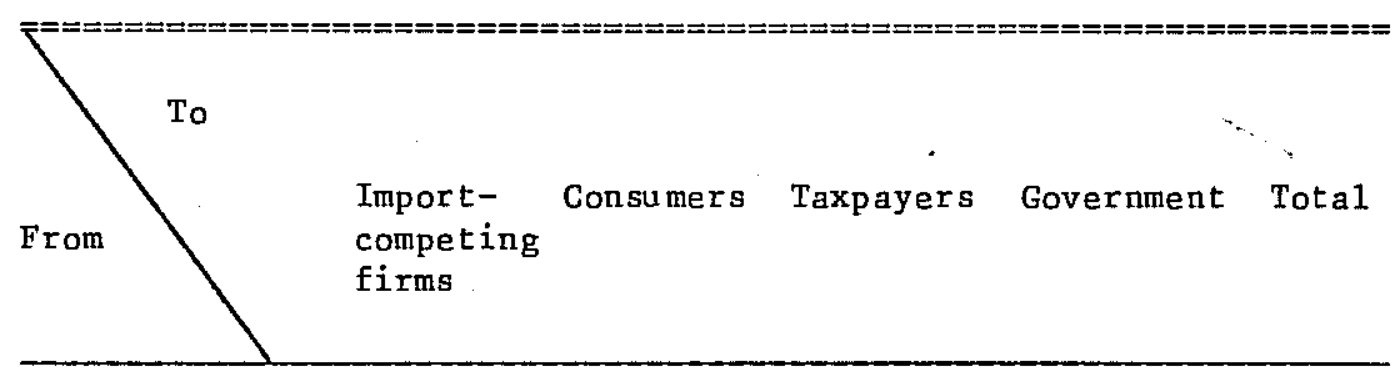

\begin{tabular}{llllll} 
Exporters & 0 & .09 & 0 & 1.42 & 1.51 \\
Consumers & .49 & - & 0 & .53 & 1.02 \\
Government & 0 & 0 & 1.95 & - & 1.95 \\
& & .49 & .09 & 1.95 & 1.95 \\
\hline
\end{tabular}


resulting changes in wages. That is to say, the transfers steming from the wage changes are already taken into account. In this sub-section, we elaborate this idea by showing that the transfers resulting from true protection are identical to those resulting from nominal protection and the associated change in wages.

We use Australia's nominal protection of $t=.15, s=.01$ and $\omega=.7$ for ar numerical illustration. Given that, we have :

$$
d=\omega t+(1-\omega) s=.7 \times .15+(1-.7) \times .01=.108 .
$$

In words, nominal wages rise by 10.8 percent. The true tariff and export tax are

$$
t^{*}=\frac{t-d}{1+d}=.038 \quad, \quad s^{*}=\frac{s-d}{1+d}=-.088 .
$$

\begin{tabular}{|c|c|c|c|}
\hline & t & $\mathbf{s}$ & $\mathrm{d}$ \\
\hline Package 1 & .15 & .01 & .108 \\
\hline Package 2 & .038 & -.088 & 0 \\
\hline
\end{tabular}

Consider now two alternative commercial policy packages :

These two packages have identical effects on internal relative prices.

\begin{tabular}{|c|c|c|c|c|c|c|}
\hline & $\frac{\mathrm{P}_{\mathrm{m}}}{\mathrm{P}_{\mathrm{x}}}$ & & $\begin{array}{c}\mathrm{P}^{\mathrm{m}} \\
\frac{\mathrm{P}_{\mathrm{h}}}{2}\end{array}$ & & $\frac{P_{x x}}{P_{h}}$ & $\cdot$ \\
\hline Free trade & 1 & & 1 & & 1 & \multirow{3}{*}{$=.912$} \\
\hline \multirow[b]{2}{*}{ Package 1} & $1+.15$ & \multirow{2}{*}{$=1.14$} & $1+.15$ & \multirow[b]{2}{*}{$=1.038$} & $1+.01$ & \\
\hline & $\overline{1+.01}$ & & $1+.108$ & & $\overline{1+.108}$ & \\
\hline \multirow{2}{*}{ Package 2} & $1+.038$ & \multirow{2}{*}{$=1.14$} & $1+.038$ & \multirow[t]{2}{*}{$=1.038$} & $1-.088$ & \multirow[t]{2}{*}{$=.912$} \\
\hline & $1-.088$ & & 1 & & 1 & \\
\hline
\end{tabular}
This can be seen as follows: 
In the above, we have chosen units such that all nominal prices are unity under free trade. Clearly, the two sets of commercial policies are equivalent. Another way of stating this is to say that if we imposed $t=.038$ and $s=-.088$, then wages would indeed be constant :

$$
\mathrm{d}=\omega t+(1-\omega) \mathrm{s}=.7 \times .038+(1-.7)(-.088)=0 .
$$

As a11 relative prices are the same under the two packages and as the transfers depend only on the relative prices, it follows that the transfers must also be the same. Consequently, our transfer matrix computed from $t^{*}, s^{*}$ and $d=0$ is exactly the same as that which would be obtained by using instead $t, s$ and $d=w t+(1-\omega) s$.

\section{CONCLUDING COMMENTS}

In this paper we have used the Clements-Sjaastad (1985) model to answer the question, who pays for protection? That model draws a sharp distinction between the initial effects of protection and the ultimate effects. The initial effects are related solely to the nominal rates of assistance, which are determined by policy makers. Many of thesè initial effects are passed onto other economic agents, so that the ultimate effects of protection are quite different from the initial effects. Just as who bears the economic incidence of a certain tax is almost always different from who writes the cheque to pay the tax, so is the ultimate effect of protection different from nominal protection.

The ultimate effects of protection are summarized by what is known as the "true" rates of protection, or true protection for short. True protection depends on the structure of the economy, something which is 
not under the control of policy makers. Consequent1y, true protection can be substantially different from nominal protection, implying that the ultimate effects of protection can be very different from what policy makers believe that to be. This indeed seems to be the case as clements and Sjaastad (1985) have found that in a number of countries protection acts as a substantial implicit tax on the countries' exporters; and it would be very surprising to find governments knowingly pursuing policies which discriminate against the country's exports.

The Clements-Sjaastad model was applied to Australia where the nominal tariff-equivalent of all forms of import protection is 15 percent and the nominal export subsidy-equivalent of all forms of assistance for exports is 1 percent. This application revealed that these policies inflated nominal wages and other costs by 11 percent and that true protection received by the import-competing firms is only 4 percent. Therefore, the effect of nominal protection on wages erodes much of its protective effeat for the import-competing sector. Furthermore, the application also revealed that the exporters are subject to a true rate of "assistance" of -9 percent, i.e. they are subject to a fairy substantial implicit tax. The mechanism by which the tax is transmitted to the exporters is the higher wages, which, in turn, inflate the whole cost structure of the export sector. As exporters face near-perfectly elastic demand conditions, they cannot pass on to their customers these cost increases; they just have to absorb them.

We then used these true rates of protection to calculate the resulting income transfers. We found that import-competing firms gain about .5 percent of G.D.P. and exporters lose 1.5 percent of G.D.P. Interestingly, consumers are net beneficiaries from protection. Although they lose as they pay higher internal prices of importables, 
there is an offsetting gain from the lower prices of exportables and the government revenue from protection. This latter effect exceeds the former, so that consumers experience a net gain. This gain is equal to about 1 percent of G.D.P. Consequently, the conclusion is that exporters are the sole losers from the protection. As Australiañ G.D.P. for 1983-84 is $\$ 187.4$ billion (ABS, 1985, p.27), the exporters' loss of income of 1.5 percent of G.D.P. is equivalent to about $\$ 2.8$ billion in 1983-84. 


\section{APPENDIX}

The classification of manufacturing industries into exportables and home goods is given in Table Al. The total value added of manufacturing in $1979-80$ is $\$ 25,614$ million (ABS, 1981). Using the value added for exportables and home goods industries within the manufacturing sector, given in Table Al, the value added for importables within manufacturing is $25,614-5,025-4,961=\$ 15,628$ million.

The contribution of the manufacturing sector to G.D.P. in 1979-80 is $\$ 23,594$ million ( $A B S, 1982 a$ ). We divide this total into exportables, importables and home goods by using the shares in total value added as follows:

\section{$\underline{\text { Value-Added }}$}

\begin{tabular}{|c|c|c|c|c|}
\hline & & 1 & 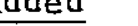 & \\
\hline & & \$million & Share & $\begin{array}{l}\text { G.D.P. } \\
\text { (\$ million) }\end{array}$ \\
\hline Manufacturing & Exportables & 5,025 & .1962 & 4,629 \\
\hline & Importables & 15,628 & .6101 & 14,395 \\
\hline & Home Goods & 4,961 & .1937 & 4,570 \\
\hline Total & & 25,614 & 1.0000 & 23,594 \\
\hline
\end{tabular}

Thus the production of manufacturing exportables is $\$ 4,629$ million, importables $\$ 14,395$ million and home goods $\$ 4,570$ million. These are the figures used in Table 2 of the text. 


\begin{tabular}{|c|c|c|}
\hline \multicolumn{2}{|c|}{ Industry } & \multirow{2}{*}{$\begin{array}{l}\text { Value Added } \\
\text { (\$million) }\end{array}$} \\
\hline $\begin{array}{l}\text { ASIC } \\
\text { Code }\end{array}$ & Description & \\
\hline
\end{tabular}

Exportables

211.

2171,2174

2175,2176 .

2343,2344

2751 .

294.

295.

3361 .

213.

215.

216.

2185.

2186,2187 .

2535 .

2641,2642

2643,2644 .

2762 .

2765.

286.

2871 .

2872 .

2874 .

3241,3242 .

3243 .
Meat products

Food Products N.E.C.

Prepared Fibres

129

Chemical Fertilizers

190

Basic Iron and Steel

1,686

Other Basic Metals

987

Agricultural Machinery

230

Tota1

5,025

Home Goods

Fruit and Vegetable Products

287

Flour and Cereal Products

212

Bread Cakes, Biscuits

488

Soft Drinks, Cordials etc

191

Beer and Malt

349

234

Joinery and Wood Prods

1,508

Newspapers and Books

Paints, Varnishes

165

Soap and Detergent

195

clay Prods, Refractories

334

Cement

150

Ready-Mixed Concrete

118

Concrete Products

147

Ship and Boat Building

241

Locomotives

342

Tota1

4,961

Source: ABS, (1981, Table 1). 


\section{REFERENCES}

Clements, K.W. and Sjaastad, L.A. (1985). How Protection Taxes

Exporters. Thames Essay No.39 (London : Trade Policy Research Centre).

Australian Bureau of Statistics (1981). Manufacturing Establishments:

Details of Operation By Industry Class, Australia, 1979-80. (ABS Cat. No. 8203.0 ).

(1982a). Australian Nationa1

Accounts: Gross Product by Industry, 1980-81. (ABS Cat. No. 5211.0).

$$
\text { (1982b). Australian Nationa1 }
$$

Accounts, National Income and Expenditure, 1980-81. (ABS Cat. No. $5204.0)$.

(1985). Monthly Summary of Statistics,

Australia, May 1985. (ABS Cat. No. 1304.0).

Industries Assistance Commission (1978). Annual Report 1977-78.

(Canberra : AGPS).

(1982). Annual Report 1981-82.

(Canberra : AGPS).

(1983). Annual Report 1982-83.

(Canberra : AGPS). 